
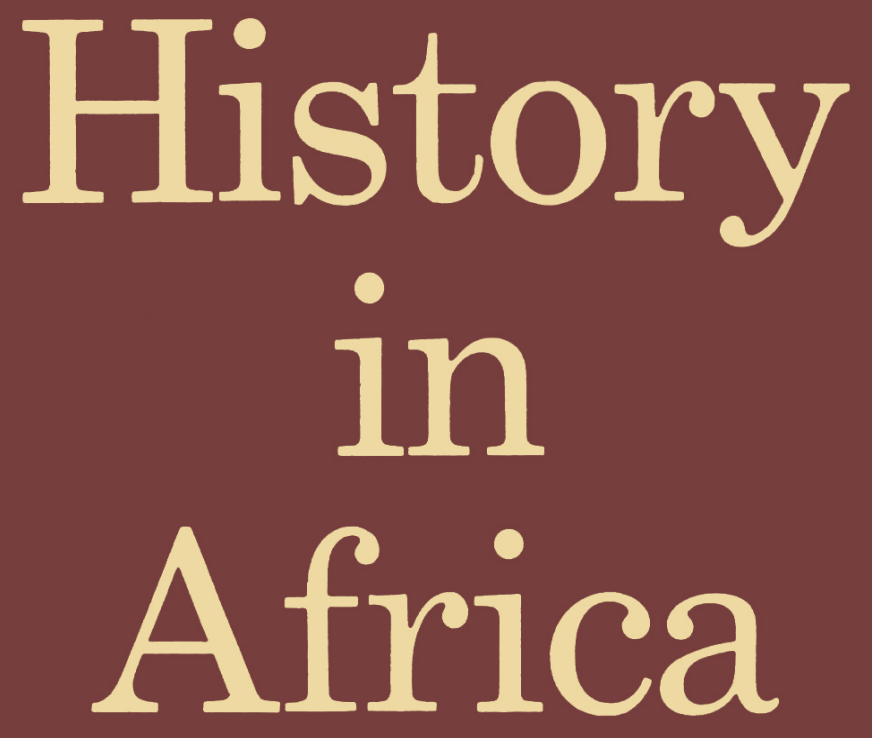

\title{
A JOURNAL OF METHOD
}

\section{David Henige, Editor}




\title{
HISTORY IN AFRICA
}

\section{EDITORIAL ADVISORY BOARD}

\author{
A.E. Afigbo (University of Nigeria, Nsukka) \\ P.D. Curtin (University of Wisconsin, Madison) \\ J.D. Fage (Centre of West African Studies, University of Birmingham) \\ S. Feierman (University of Wisconsin, Madison) \\ P.E.H. Hair (University of Liverpool) \\ D.H. Jones (SOAS, University of London) \\ R.C.C. Law (University of Stirling) \\ B.M. Metzger (Princeton Theological Seminary) \\ J.C. Miller (University of Virginia) \\ A. Teixeira da Mota (Lisbon) \\ M. Twaddle (Institute of Commonwealth Studies, University of London) \\ A. van Dantzig (University of Ghana) \\ J. Vansina (Universiteit Katolieke te Leuven)
}

History in Africa is published annually by the African Studies Association. Permission to reproduce materials from History in Africa should be obtained from the African Studies Association. Subscription and other business correspondence should be sent to the African Studies Association, 218 Shiffman Center, Brandeis University, Waltham, Massachusetts 02154. Manuscripts and other editorial correspondence should be sent to David Henige, Memorial Library, University of Wisconsin, Madison, Wisconsin 53706.

Articles in History in Africa represent neither the views of the African Studies Association nor those of its officers. The Editor is responsible for the final selection of the content of History in Africa and reserves the right to reject any material deemed inappropriate for publication. Responsibility for opinions expressed and for the accuracy of facts published in articles rests solely with the individual authors. 

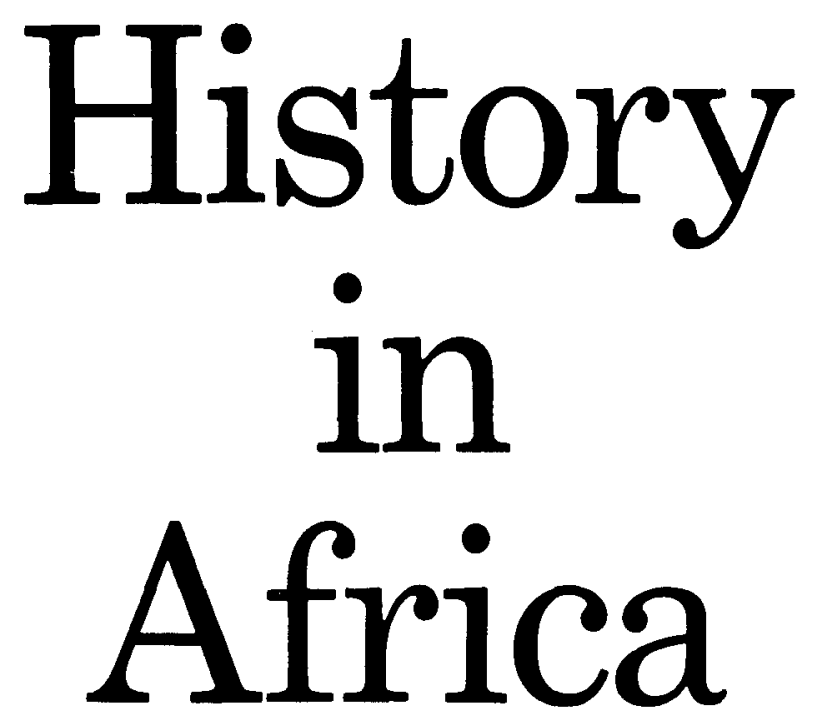

\title{
A JOURNAL OF METHOD
}

David Henige, Editor

\author{
AFRICAN STUDIES ASSOCIATION \\ Brandeis University \\ Waltham, Massachusetts 02154
}


Copyright (1) 1975 by the African Studies Association. 
The method of discovering truths is more valuable than the truths it has discovered.

Emerson 


\section{HISTORY IN AFRICA}

Volume 1 (1974)

\section{CONTENTS}

On Method: An Apologia and a Plea

David Henige

Silent Trade: Myth and Historical Evidence

P.F. de Moraes Farias

Barbot, Dapper, Davity: A Critique of Sources on Sierra Leone and Cape Mount P.E.H. Hair

News from Nowhere: Duncan and "Adofoodia"

Marion Johnson

Traditional Myths and Historians' Myths: Variations on the Singwaya Theme of Mijikenda Origins

Thomas T. Spear

On Ganda Historiography

Michael Twaddle

Willem Bosman's New and Accurate Description of the Coast of Guinea: How Accurate is It?

Albert van Dantzig

The Power of Systematic Doubt in Historical Enquiry

Jan Vansina

The Kinglists of Buganda

C.C. Wrigley

Disease and Medicine in African History: A Bibliographical Essay

K. David Patterson

The Dictionary and the Historian

Jan Vansina

Archival Reports:

The National Archives of Cameroon

Ralph A. Austen

Archives in Niger

Stephen Baier

Archival Resources in Gabon

Henry H. Bucher

Les Archives de la Société des Pères Blancs

Rene Lamey

Research Projects and Conferences

Comparative Bibliography 1974 


\author{
ABBREVIATIONS \\ BIFAN Bulletin de l'Institute Fondamental de l'Afrique Noire [Dakar] \\ IJAHS International Journal of African Historical Studies \\ JAH Journal of African History \\ THSG Transactions of the Historical Society of Ghana \\ UJ Uganda Journal \\ JRGS Journal of the Royal Geographical Society
}

